\title{
Copper in plants
}

\author{
Inmaculada Yruela
}

Estación Experimental de Aula Dei, Consejo Superior de Investigaciones Cientificas (CSIC), Apdo. 202, E-50080 Zaragoza, Spain. Email: yruela@eead.csic.es

Copper is an essential metal for normal plant growth and development, although it is also potentially toxic. Copper participates in numerous physiological processes and is an essential cofactor for many metalloproteins, however, problems arise when excess copper is present in cells. Excess copper inhibits plant growth and impairs important cellular processes (i.e., photosynthetic electron transport). Since copper is both an essential cofactor and a toxic element, involving a complex network of metal trafficking pathways, different strategies have evolved in plants to appropriately regulate its homeostasis as a function of the environmental copper level. Such strategies must prevent accumulation of the metal in the freely reactive form (metal detoxification pathways) and ensure proper delivery of this element to target metalloproteins. The mechanisms involved in the acquisition of this essential micronutrient have not been clearly defined although a number of genes have recently been identified which encode potential copper transporters. This review gives a briefly overview of the current understanding of the more important features concerning copper toxicity and tolerance in plants, and brings information of recent findings on copper trafficking including copper detoxification factors, copper transporters and copper chaperones.

Key words: copper homeostasis, copper transporters, detoxification, metalloproteins, toxicity.

Cobre em plantas: Cobre é um metal essencial para o crescimento e desenvolvimento normal de plantas, apesar de também ser potencialmente tóxico. Participa de vários processos fisiológicos, sendo co-fator essencial para muitas metaloproteínas; no entanto, aparecem problemas quando o cobre está presente em excesso nas células. Isso inibe o crescimento de plantas e impede importantes processos celulares, como, por exemplo, o transporte de elétrons na fotossíntese. Desde que o cobre tanto é um co-fator essencial como um elemento tóxico, diferentes estratégias, com uma rede complexa de vias de transporte do metal, evoluem em plantas de forma a regular apropriadamente sua homeostase em função de mudanças ambientais do nível de cobre. Tais estratégias devem impedir o acúmulo do metal na forma reativa livre (vias de destoxificação) e assegurar a alocação adequada do metal a metaloproteína destino. Os mecanismos envolvidos na aquisição desse micronutriente essencial não foram claramente definidos, apesar de vários genes que codificam para transportadores de cobre terem sido recentemente identificados. Esta revisão descreve, brevemente, o atual conhecimento sobre as principais características da toxicidade e tolerância de plantas ao cobre, assim como as recentes descobertas sobre o transporte de cobre, incluindo fatores de destoxificação, transportadores e chaperonas de cobre.

Palavras-chave: homeostase de cobre, destoxificação, metaloproteínas, toxicidade, transportadores de cobre.

\section{INTRODUCTION}

Copper $(\mathrm{Cu})$ is an essential redox-active transition metal that is involved in many physiological processes in plants because it can exist in multiple oxidation states in vivo. Under physiological conditions $\mathrm{Cu}$ exists as $\mathrm{Cu}^{2+}$ and $\mathrm{Cu}^{+} . \mathrm{Cu}$ acts as a structural element in regulatory proteins and participates in photosynthetic electron transport, mitochondrial respira- tion, oxidative stress responses, cell wall metabolism and hormone signaling (for a review see Marschner, 1995; Raven et al., 1999). Cu ions act as cofactors in many enzymes such as $\mathrm{Cu} / \mathrm{Zn}$ superoxide dismutase (SOD), cytochrome c oxidase, amino oxidase, laccase, plastocyanin and polyphenol oxidase. At the cellular level, $\mathrm{Cu}$ also plays an essential role in signaling of transcription and protein trafficking 
machinery, oxidative phosphorylation and iron mobilization. Thus, plants require $\mathrm{Cu}$ as an essential micronutrient for normal growth and development; when this ion is not available plants develop specific deficiency symptoms, most of which affect young leaves and reproductive organs. The redox properties that make $\mathrm{Cu}$ an essential element also contribute to its inherent toxicity. Redox cycling between $\mathrm{Cu}^{2+}$ and $\mathrm{Cu}^{+}$can catalyze the production of highly toxic hydroxyl radicals, with subsequent damage to DNA, lipids, proteins and other biomolecules (Halliwell and Gutteridge, 1984). Thus, at high concentrations, $\mathrm{Cu}$ can become extremely toxic causing symptoms such as chlorosis and necrosis, stunting, leaf discoloration and inhibition of root growth (van Assche and Clijsters, 1990; Marschner, 1995). At the cellular level, toxicity may result from i) binding to sulfhydryl groups in proteins, thereby inhibiting enzyme activity or protein function; ii) induction of a deficiency of other essential ions; iii) impaired cell transport processes; iv) oxidative damage (van Assche and Clijsters, 1990; Meharg, 1994).

Nevertheless, either deficient or in excess, $\mathrm{Cu}$ can cause disorders in plant growth and development by adversely affecting important physiological process in plants. In particular photosynthetic electron transport is altered under both $\mathrm{Cu}$ deficiency and excess $\mathrm{Cu}$ conditions. Thus, for healthy plant growth and development $\mathrm{Cu}$ must be acquired from the soil, transported throughout the plant, distributed and compartmentalized within different tissues and its content carefully regulated within different cells and organelles. For this purpose, plants -like all other organismshave homeostatic mechanisms to maintain the correct concentrations of essential metal ions. Membrane transport systems are likely to play a central role in these processes.

Although the mineral nutrition of higher plants is of fundamental importance to agriculture and human health, many basic questions remain unanswered, particularly in relation to the accumulation of essential heavy metals. How do plants ensure that all tissues receive an adequate supply of the heavy metals required for vital cellular processes? How do plants prevent these metals from accumulating to toxic levels? These are some questions of fundamental importance in plant biology, which underlie an area of research that is emerging now that the necessary molecular tools are available. In fact the mechanisms that contribute to $\mathrm{Cu}$ homeostasis are just beginning to be elucidated in higher plants since $\mathrm{Cu}$ ions are essential components of a variety of enzymes, transcription factors and other proteins. The use of genetic and molecular techniques, such as sequence comparison to identify trans- porters and functional complementation of yeast mutants and plant transformation to regulate gene activities, has been crucial for the progress achieved in this area. A wide range of gene families and proteins are being identified in plants that are likely to be involved in $\mathrm{Cu}$ homeostasis. $\mathrm{Cu}$ homeostasis is also receiving a growing interest in plant research since it is implicated in responses to the oxidative damage produced by environmental stress. Mechanisms must exist to satisfy the requirements of cellular metabolism and at the same time protect cells from toxic effects. At the cellular level, specific transporters are presumably responsible for the uptake and secretion of metal ions, and there may be additional transporters that allow sequestration into organelles. Thus, the characterization of $\mathrm{Cu}$ transporters will help to elucidate how $\mathrm{Cu}$ is incorporated into plant cells and transported to subcellular proteins and compartments. In particular, the interaction of metal chaperones with transporters deserves attention since this may have important implications for sequestration of metals within intracellular stores. During the last ten years a rapid progress has been made in this area. Thus, heavy metal transport is a very exciting and fast developing field in plant biology.

\section{Copper deficiency in plants}

$\mathrm{Cu}$ concentrations in cells need to be maintained at low levels since this element is extremely toxic in view of its high redox properties. The average content of $\mathrm{Cu}$ in plant tissue is $10 \mu \mathrm{g} \cdot \mathrm{g}^{-1}$ dry weight (Baker and Senef, 1995). The critical free $\mathrm{Cu}$ concentration in nutrient media (below which $\mathrm{Cu}$ deficiency occurs) ranges from $10^{-14}$ to $10^{-16} \mathrm{M}$. Plants usually find a variable supply of $\mathrm{Cu}$ in the soil since typically soil solution concentrations range from $10^{-6}$ to $10^{-9}$ $\mathrm{M}$, but plants may still need to solubilize and reduce the metal. No specific transporters involved in $\mathrm{Cu}$ uptake from the environment have been characterized to date but there is evidence that $\mathrm{Cu}$ is reduced.

$\mathrm{Cu}$-deficient plants show a change in the expression of a series of genes and activation of morphological changes such as in root and leaf architecture. Typical symptoms of $\mathrm{Cu}$ deficiency appear first at the tips of young leaves and then extend downward along the leaf margins. The leaves may also be twisted or malformed and show chlorosis or even necrosis (Marschner, 1995). Cu deficiency was found to reduce photosystem I (PSI) electron transport due to decreased formation of plastocyanin (Baszynski et al., 1978; Shikanai et al., 2003) which is the major target site of $\mathrm{Cu}$ deficiency in photosynthesis. Decrease in phosystem II 
(PSII) activity was also observed in Cu-deficient chloroplasts (Droppa et al., 1987; Henriques, 1989). Droppa et al. (1987) concluded that severe $\mathrm{Cu}$ deficiency results in changes in the thylakoid membranes and modifies the ambient of the PSII acceptor side. They also noticed the absence of a 29 $\mathrm{kDa}$ polypeptide, which is probably a component of CP29, a minor chlorophyll-protein of PSII. Cu-deficient plants show disintegration of the thylakoid membranes of chloroplasts (Baszynski et al., 1978; Henriques, 1989) as well as decreased pigment (chlorophylls and carotenoids) content, reduced plastoquinone synthesis and lower unsaturated $\mathrm{C} 18$ fatty acid contents (Barón et al., 1992).

The up- and down- regulation of genes directing those events involve a series of molecular mechanisms that begin with the plant "sensing" the deficiency and then transmitting the signal along transduction pathways through the plant vascular system. Signals between the aerial parts of the plants, including the apical meristem, and the roots lead to the activation or inactivation of transcription factors that influence expression of specific genes. How plants detect and respond to deficiencies in $\mathrm{Cu}$ and other essential micronutrients is still obscure.

\section{Copper toxicity in plants}

Toxic levels of $\mathrm{Cu}$ occur naturally in some soils whereas others may contain high levels of $\mathrm{Cu}$ as a result of the anthropogenic release of heavy metals into the environment through mining, smelting, manufacturing, agriculture and waste disposal technologies. At concentrations above those required for optimal growth $\mathrm{Cu}$ was shown to inhibit growth and to interfere with important cellular processes such as photosynthesis and respiration (Marschner, 1995; Prasad and Strzalka, 1999). Plants grown in the presence of high levels of $\mathrm{Cu}$ normally show reduced biomass and chlorotic symptoms. A lower content of chlorophyll and alterations of chloroplast structure and thylakoid membrane composition was found in leaves under such growth conditions (Baszynski et al., 1988; Lidon and Henriques, 1991; 1993; Ciscato et al., 1997; Pätsikkä et al., 1998; Quartacci et al., 2000). In particular, degradation of grana stacking and stroma lamellae, increase in the number and size of plastoglobuli, and appearance of intrathylakoidal inclusions were observed. It was proposed that $\mathrm{Cu}$ interferes with the biosynthesis of the photosynthetic machinery modifying the pigment and protein composition of photosynthetic membranes (Lidon and Henriques, 1991; Maksymiec et al., 1994). Furthermore, lipid peroxidations, decreases of lipid content and changes in fatty acid composition of thylakoid membranes were observed (Sandmann and Böger, 1980; Luna et al., 1994; Maksymiec et al., 1994). As a consequence of such modifications, alteration of PSII membrane fluidity was found (Quartacci et al., 2000). On the other hand, the decrease of the photochemical activity caused by $\mathrm{Cu}$ is accompanied in vivo by an alteration of the structure and composition of the thylakoid membranes, which can influence the conformation and function of the photosystems (Baszynski et al., 1988, Ouzounidou et al., 1992, Lidon et al., 1993). Baszynski and Kruppa (1995) proposed that those processes induced by $\mathrm{Cu}$ could involve either the destruction of the oxygen-evolving complex polypeptide composition or the interaction with ions necessary for proper functioning of the complex such as $\mathrm{Mn}, \mathrm{Ca}$ and $\mathrm{Cl}$.

It is well known that transition metals like $\mathrm{Cu}$ catalyze the formation of hydroxyl radicals $(\mathrm{OH})$ from the non-enzymatic chemical reaction between superoxide $\left(\mathrm{O}_{2}{ }^{-}\right)$and $\mathrm{H}_{2} \mathrm{O}_{2}$ (Haber-Weiss reaction) (Halliwell and Gutteridge, 1984). Hence, the presence of excess $\mathrm{Cu}$ can cause oxidative stress in plants and subsequently increase the antioxidant responses due to increased production of highly toxic oxygen free radicals. Accordingly, it was observed that excess $\mathrm{Cu}$ in plants led to oxidative stress inducing changes in the activity and content of some components of the antioxidative pathways (i.e., ascorbate peroxidase (APX), monodehydroascorbate reductase (MDHAR), dehydroascorbate reductase (DHAR), glutathione reductase (GR), superoxide dismutases (SODs), guiacol peroxidase) (De Vos et al., 1992; Luna et al., 1994; Stohs and Bagchi, 1995; Navari-Izzo et al., 1998; Gupta et al., 1999; Drazkiewicz et al., 2003; Wang et al., 2004). The antioxidant responses were observed in leaves and roots being both $\mathrm{Cu}$-concentration dependent and time-dependent. The ascorbate-glutathione cycle has been reported to be involved in response to excess $\mathrm{Cu}$ (Gupta et al., 1999; Drazkiewicz et al., 2003).

The mechanism of $\mathrm{Cu}$ toxicity on photosynthetic electron transport has been extensively studied in vitro and it was found that PSII (figure 1) is a more sensitive site to $\mathrm{Cu}$ toxicity (for review see Droppa and Horváth, 1990; Barón et al., 1995) than photosystem I (PSI) (Ouzounidou et al., 1997). The most apparent effect of Cu toxicity on PSII is the inhibition of oxygen evolution accompanied by quenching of variable fluorescence (Hsu and Lee, 1988; Samson et al., 1988; Mohanty et al., 1989). Both the acceptor and the donor sides of PSII were suggested as the main targets of $\mathrm{Cu}$ toxic action. On the PSII reducing side, the $\mathrm{Q}_{\mathrm{B}}$ binding site 
(Mohanty et al., 1989) and the Pheo-Fe-Q $\mathrm{A}_{\mathrm{A}}$ domain (Yruela et al., 1991, 1992, 1993, 1996a) have been reported as the most sensitive sites for $\mathrm{Cu}$ toxicity. Evidence that $\mathrm{Cu}$ impairs the function of the oxidizing side were also reported (CedeñoMaldonado and Swader, 1972; Vierke and Struckmeier, 1977; Shioi et al., 1978a,b; Bohner et al., 1980; Samuelsson and Öquist, 1980). Some authors (Schröder et al., 1994, Arellano et al., 1995) suggested that the electron flow from $\mathrm{Tyr}_{\mathrm{z}}$ to $\mathrm{P} 680^{+}$is blocked at toxic $\mathrm{Cu}$ concentrations. Králova et al. (1994) and Sersen et al. (1997) proposed that Cu interacts not only with $\mathrm{Tyr}_{\mathrm{z}}$, but also with $\mathrm{Tyr}_{\mathrm{D}}$ on D2 protein. A possible direct interaction between $\mathrm{Cu}$ and $\mathrm{Ca}$ at the oxidizing side of PSII was also shown in vitro (Sabat, 1996) and in vivo (Maksymiec and Baszynski, 1999).

Additional effects of $\mathrm{Cu}$ toxicity on both the donor side, affecting the Mn-cluster and the extrinsic proteins of the oxygen-evolving-complex, and the acceptor side, interacting with the non-heminic $\mathrm{Fe}^{2+}$ and cytochrome (Cyt) $b_{559}$ have been reported (Renger et al., 1993; Jegerschöld et al., 1995, 1999; Yruela et al., 1996b; Sersen et al., 1997; Yruela et al., 2000; Burda et al., 2003; Bernal et al., 2004). The extrinsic proteins of 33,24 and $17 \mathrm{kDa}$ of the oxygen-evolving complex of PSII were removed by high $\mathrm{Cu}$ concentration treatments. With respect to Cyt $b_{559}$, Yruela et al. (1996b) found that $\mathrm{Cu}$ decreased the level of the photoreduced $\mathrm{Cyt}$ $b_{559}$ and slowed down its rate of photoreduction. Jegerschöld et al. (1995) observed conversion of the high potential (HP) form of Cyt $b_{559}$ to the low potential (LP) form at high $\mathrm{Cu}$ concentrations. Since $\mathrm{Cu}$ ions have high affinity for histidine

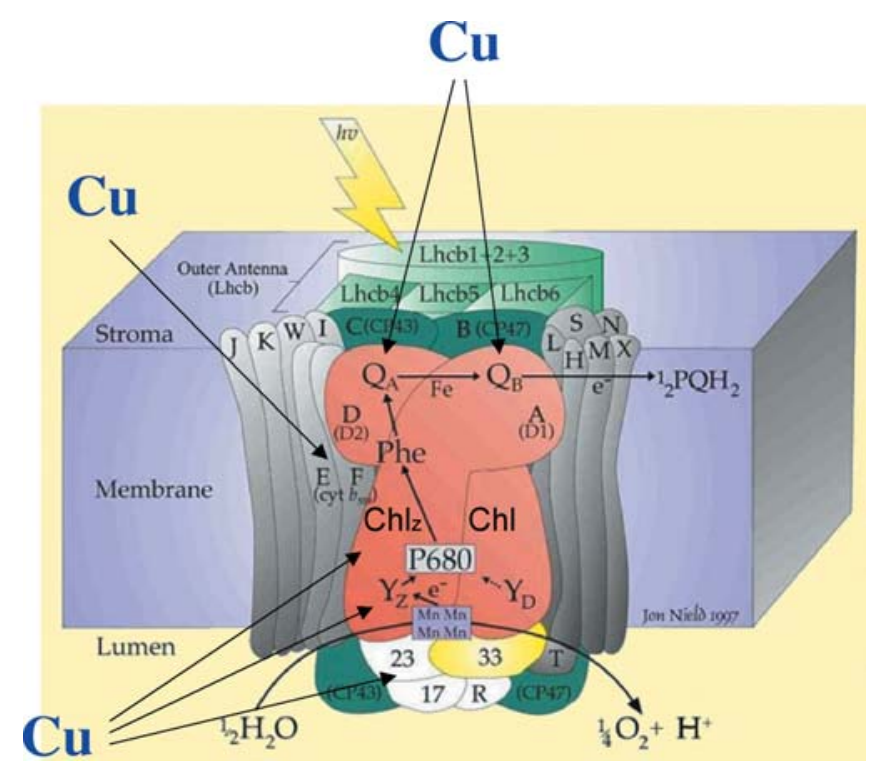

Figure 1. Scheme of toxic $\mathrm{Cu}$ action sites in photosystem II from plants. residues it is reasonable to assume that $\mathrm{Cu}$ ions interact with the histidine residue(s) coordinating the Cyt $b_{559}$ heme group (Roncel et al., 2001) leading to changes in the Cyt $b_{559}$ redox state. On the other hand, Burda et al. (2003) found that high $\mathrm{Cu}$ concentrations, apart from the inhibition of oxygen evolution, changed the initial S-state distribution of the oxygen-evolving complex, oxidized both the LP and the HP forms of Cyt $b_{559}$, and enhanced the formation of the $\mathrm{Chl}_{\mathrm{z}}^{+}$ radical. These authors proposed that this finding could be responsible for fluorescence quenching in PSII.

The different sites of $\mathrm{Cu}$ action on PSII suggested in the literature certainly depend on the relative $\mathrm{Cu}$ to reaction center ratio used in the investigations. This fact complicates the comparison and interpretation of the published results and shows the need to distinguish between in vitro $\mathrm{Cu}$ effects on PSII obtained at low and high $\mathrm{Cu}$ concentrations. Low $\mathrm{Cu}$ concentrations $(\mathrm{Cu}$ per PSII reaction center unit $\leq 250$ ) that cause around $50 \%$ inhibition of variable chlorophyll $a$ fluorescence and oxygen evolution activity did not affect the polypeptide composition of PSII. However, the 33, 24 and 17 $\mathrm{kDa}$ extrinsic proteins of the oxygen-evolving complex of PSII are removed when samples are treated with higher $\mathrm{Cu}$ concentrations ( $\mathrm{Cu}$ per PSII reaction center unit $>250$ ). The LCHII antenna complex and D1 protein of the PSII reaction center are not affected even at these elevated $\mathrm{Cu}$ concentrations (Yruela et al., 2000). These findings might indicate that the initial inhibition of the PSII electron transport and oxygenevolving activity induced by the presence of toxic $\mathrm{Cu}$ could occur before the damage to the oxygen-evolving complex.

The interaction of $\mathrm{Cu}$ toxicity with photoinhibitory and recovery processes on PSII has been also investigated (Yruela et al., 1996b, Pätsikkä et al., 1998) demonstrating that $\mathrm{Cu}$ enhances the adverse effects of light. The photosynthetic activity decreases when oxygenic organisms are exposed to prolonged illumination with high light intensities. This process, which includes the functional impairment of PSII electron transport and the structural damage of the PSII reaction center, is known as photoinhibition (Aro el al., 1993). $\mathrm{Cu}$ increases susceptibility to photoinhibition in isolated thylakoids (Cedeño-Maldonado and Swader, 1972; Pätsikkä et al., 2001) or PSII-enriched membrane preparations (Yruela et al., 1996b). Considering that $\mathrm{Cu}$ is an efficient catalyst in the formation of reactive oxygen species (ROS), it was suggested that the increased $\mathrm{Cu}$ toxicity by light during photoinhibition is due to production of hydroxyl radicals (Yruela et al., 1996b). A different proposal was given by Pätsikkä et al. (2002) to explain the severe effects 
caused by the presence of high $\mathrm{Cu}$ concentrations during photoinhibition in vivo. These authors suggested that the reduced chlorophyll content observed in plant leaves grown in the presence of high $\mathrm{Cu}$ concentrations made leaves more susceptible to photoinhibition as a consequence of a $\mathrm{Cu}$-induced Fe deficiency. Since adding excess Fe in the hydroponic growth medium reduced $\mathrm{Cu}$ toxicity symptoms a competition between $\mathrm{Cu}$ and $\mathrm{Fe}$ uptake mechanisms at the root level was proposed. The $\mathrm{Cu}$ effect on Cyt $b_{559}$ under photoinhibitory conditions was also investigated. These studies indicated that Cyt $b_{559}$ is affected after PSII centers are photoinhibited and that the HP form of Cyt $b_{559}$ is more sensitive to the toxic $\mathrm{Cu}$ action than the LP form under photoinhibitory conditions (Bernal et al., 2004).

\section{Copper uptake and transport mechanisms}

$\mathrm{Cu}$ acquisition and transport into and within cells is relatively little known in plants. However, recently rapid progress has been made, particularly with the application of the knowledge of transport processes in yeast to other eukaryote organisms (Eide, 1998; Nelson, 1999). Consequently, several families of heavy metal transporters have been identified (for reviews see Fox and Guerinot, 1998; Himelblau and Amasino, 2000; Williams et al., 2000; Markossian and Kurganov, 2003) (figure 2).

P-type ATPase Cu-transporters: P-type heavy metal ATPase have been identified in a wide range of organisms including

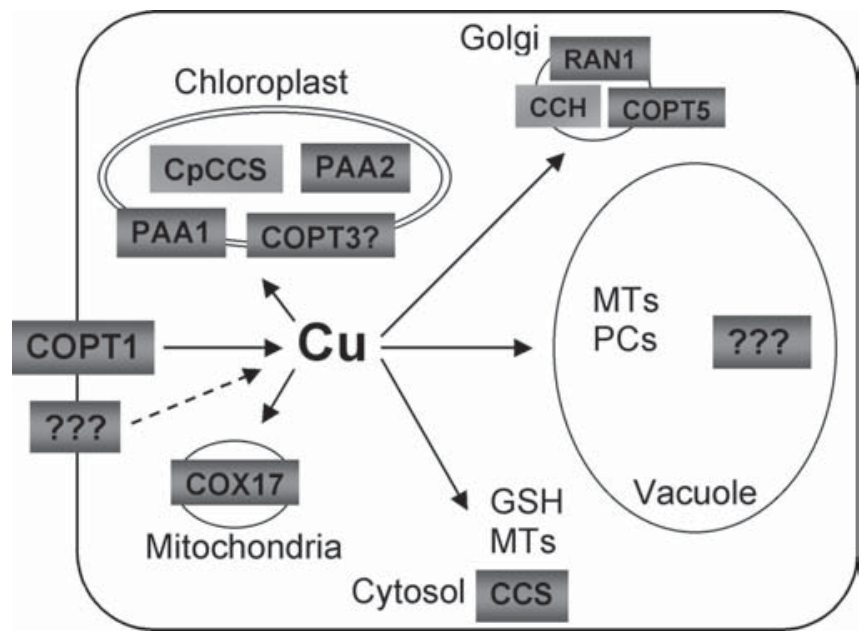

Figure 2. Scheme of identified transport pathways for $\mathrm{Cu}$ in plant cells. The cell membrane transporters (COPT1, COPT3, COPT5, COX17, PAA1, PAA2, RAN1), copper chaperones (CCH, CCS, $\mathrm{CpCCS}$ ) and detoxification factors (metallothioneins (MTs), phytochelatins (PCs) or glutathione (GSH)) are shown. plants and are implicated in the transport of a range of essential and potentially toxic metals across cell membranes (i.e., $\mathrm{Cu}^{2+}, \mathrm{Zn}^{2+}, \mathrm{Cd}^{2+}, \mathrm{Pb}^{2+}$ ). They are a subgroup of the large superfamily of P-type ATPases, which use ATP to pump a variety of charged substrates across biological membranes and are distinguished by the formation of a phosphorylated intermediate during the reaction cycle. Heavy metal ATPases have been classified as type 1B ATPases and, together with the closely related type 1A ATPases (which are thought to be involved in $\mathrm{K}^{+}$transport), they are considered to constitute a monophyletic group (Palmgren et al., 1998).

Solioz and Vulpe (1996) defined the heavy metal P-type ATPases as CPx-ATPases because they share the common feature of a conserved intramembranous cysteine-prolinecysteine, cysteine-proline-histidine or cysteine-proline-serine motif (CPx motif) which is thought to function in heavy metal transduction. The first CPx-ATPase reported in plants was PAA1 (P-type ATPase of Arabidopsis 1) from Arabidopsis thaliana (Tabata et al., 1997). This metal-transporter was identified originally by its sequence similarity to cyanobacterial CtaA protein. In view of the similarity between plastids and cyanobacteria, P-type ATPases such as PAA1, which are more similar to cyanobacterial transporters than to RAN1, were proposed to be involved in $\mathrm{Cu}$ delivery to chloroplasts.

Sequence comparisons generally group the type 1B ATPases into two further classes: i) those transporting monovalent cations, $\mathrm{Cu} / \mathrm{Ag}$ and ii) those transporting divalent cations, $\mathrm{Cd} / \mathrm{Pb} / \mathrm{Zn} / \mathrm{Co}$ (Axelsen and Palmgren, 2001; Cobbet et al., 2003). Biochemical studies using membrane vesicles indicate that the substrate for 1B heavymetal-transporting P-type ATPases is $\mathrm{Cu}(\mathrm{I})$ rather than $\mathrm{Cu}$ (II) (Voskoboinik et al., 2002). The recent completion of the Oryza sativa (rice) genome has allowed the comparison of the full complement of P-type ATPase genes in two different plant species, Arabidopsis thaliana and Oryza sativa. Eight members of the type 1B subfamily have been found (Baxter et al., 2003). Since the nomenclature of these eight members is confused, Baxter et al. (2003) have designated these as HMA1 to HMA8 although three of them, HMA6, HMA7 and HMA8, had previous designations, PAA1, RAN1 and PAA2, respectively. Four members of this family HMA5, HMA6 (PAA1), HMA7 (RAN1) and HMA8 (PAA2) are the most closely related to the $\mathrm{Cu} /$ Ag subclass. HMA7 (RAN1) was identified in a genetic screen for plants with an unusual response to the ethylene antagonist trans-cyclooctene, underscoring the critical role of $\mathrm{Cu}$ in the ethylene-signaling pathway (Hirayama et 
al., 1999). This role is explained by the fact that ethylene receptors are $\mathrm{Cu}$-dependent proteins (Rodríguez et al., 1999; Hiramaya and Alonso, 2000). Thus HMA7 (RAN1) is involved in ethylene signaling by transporting $\mathrm{Cu}$ to the secretory pathway, where it is required for the formation of functional ethylene receptors (Woeste and Kieber, 2000). The plant hormone ethylene is an important signal in many abiotic stress situations but also in plant pathogen interaction. Shikanai et al. (2003) demonstrated that HMA6 (PAA1) is responsible for the delivery of $\mathrm{Cu}$ to chloroplasts, which provides the cofactor for the stromal enzyme $\mathrm{Cu} / \mathrm{Zn}$ superoxide dismutase $(\mathrm{Cu} / \mathrm{ZnSOD})$ and for the thylakoid lumen protein plastocyanin, two proteins involved in antioxidant enzymatic activity and photosynthetic electron transport function, respectively. Paal mutants have a high chlorophyll fluorescence phenotype arising from impaired photosynthetic electron transport apparently because of a deficiency in holoplastocyanin (Shikanai et al., 2003). The phenotype can be restored by the addition of excess $\mathrm{Cu}$ to the growth medium. HMA5 and HMA8 (PAA2) are the most similar in sequence to HMA7 (RAN1) and HMA6 (PAA1), respectively (Baxter et al., 2003), however their precise functions have not been described. Since HMA8 (PAA2) shows similarity to PacS transporter from cyanobacteria and has a chloroplast transit sequence it has been suggested that it could be involved in $\mathrm{Cu}$ transport through the thylakoid membrane (Pilon et al., unpublished data). The remaining four type 1B ATPases in Arabidopsis thaliana HMA1, HMA2, HMA3 and HMA4 are most closely related to the divalent cation transporters from prokaryotes and have no apparent counterparts in non-plant eukaryotes. The roles of these in heavy metal homeostasis or tolerance in plants have not yet been described. The data of partial sequences and expressed sequence tags obtained suggest these ATPases occur in a variety of plant species. Recently, the RAN1 Cutransporter has been found in Brassica napus (BnRAN1) (Southron et al., 2004).

COPT copper transporters: Another widespread family of $\mathrm{Cu}$ transporters, the COPT proteins, has been identified in plants by sequence homology with the eukaryotic $\mathrm{Cu}$ transporters named $\mathrm{Ctr}$ or by functional complementation in yeast. Five members of this family, COPT1-5, have been found in Arabidopsis thaliana. The first one, COPT1 was identified by the ability of its cDNA to functionally complement a Saccharomyces cerevisiae mutant defective in high-affinity Cu uptake (Kampfenkel et al., 1995). The COPT1 transporter allows the entrance of $\mathrm{Cu}$ into cells (Kampfenkel et al., 1995; Sancenón et al., 2003). All members belonging to the Ctr family contain three predicted transmembrane segments and most posses a N-terminal Met- and His- rich putative metal binding domain (for reviews Peña et al., 1999; Labbé and Thiele, 1999; Harris, 2000; Puig and Thiele, 2002). The existence of three COPT groups according to the number of $\mathrm{N}$-terminal Met- and His- rich boxes has been proposed. The first one, including COPT1 and COPT2, displays the more high-affinity $\mathrm{Cu}$ transporter features. Metal competition experiments suggest that Arabidopsis COPT1, as for other Ctr1 family members, is a high-affinity transporter with specificity for $\mathrm{Cu}(\mathrm{I})$ (Sancenón et al., 2003). The COPT1 gene is expressed in embryos, trichomes, stomata, pollen and roots tips. It plays an important physiological role in $\mathrm{Cu}$ acquisition and accumulation since it is required for growth under $\mathrm{Cu}$ limiting conditions. Its participation in root elongation and pollen development has been also described (Sancenón et al., 2004). The second group includes the COPT3 and COPT5 transporters having only one Met- and His- rich box, which show an intermediate level of both complementation and $\mathrm{Cu}$ transport rate. Putative target sequences to the chloroplast and the secretory pathway have been predicted for COPT3 and COPT5, respectively. Finally, COPT4 represents a third group showing high level expression in roots that lacks Metresidues and motifs essential for Ctr1-mediated high-affinity $\mathrm{Cu}$ transport. These findings suggest an indirect role in $\mathrm{Cu}$ transport (Sancenón et al., 2004).

Copper chaperones: The $\mathrm{Cu}$ chaperones belong to a new family of cytosolic, soluble, low-molecular-weight metal-receptor proteins named metallochaperones, and are involved in the intracellular trafficking of metal ions. Different molecular chaperones involved in protein folding have been found differing in their functions. $\mathrm{Cu}$ chaperones have a critical biological function to transport $\mathrm{Cu}$ in the cytoplasm to the site of utilization by $\mathrm{Cu}$-dependent proteins. Consequently, $\mathrm{Cu}$ chaperones bind and deliver $\mathrm{Cu}$ ions to intracellular compartments and insert the $\mathrm{Cu}$ into the active sites of specific partners, the $\mathrm{Cu}$-dependent enzymes. Thus, these proteins prevent inappropriate $\mathrm{Cu}$ interaction with other cellular components. In plants, three different members of the $\mathrm{Cu}$ chaperone family, $\mathrm{CCH}, \mathrm{COX} 17$ and $\mathrm{CCS}$, have been identified and characterized at different levels. The Arabidopsis $\mathrm{CCH}$ gene, highly homologous to the yeast ATX1 (Himelblau et al., 1998) has been the most extensively studied of the three $\mathrm{Cu}$ chaperones in plants (Mira et al., 2001a,b). High levels of 
$\mathrm{CCH}$ expression were found in stems of this plant. Recently, a $\mathrm{CCH}$ chaperone has been identified by differential display in tomato (Lycopersicon esculentum; LeCCH) infected with the fungal pathogen Botrytis cinerea (Company and González-Bosch, 2003) suggesting an interesting relationship between $\mathrm{Cu}$ homeostasis and plant defense responses. The plant $\mathrm{CCH}$ gene expression has been related to oxidative stress and senescence. It has been proposed that $\mathrm{CCH}$ by homology to its counterpart in yeast binds $\mathrm{Cu}(\mathrm{I})$ and interacts directly with a P-type ATPase $\mathrm{Cu}$ transporter (probably RAN1), its physiological partner. The COX17 gene was recently isolated in Arabidopsis (AtCOX17). It encodes a protein that shares sequence similarity to $\mathrm{COX} 17$, a Cu-chaperone from yeast that might mediate the delivery of $\mathrm{Cu}$ to the mitochondria for the assembly of a functional cytochrome oxidase complex (Balandin and Castresana, 2002). The gene expression of $A t C O X 17$ was activated in response to excess $\mathrm{Cu}$ treatment indicating that this $\mathrm{Cu}$-chaperone could be involved in a tolerance function like metallothioneins which are also induced by high concentrations of metals (Zhou and Goldsbrough, 1994). The AtCOX17 chaperone could supply $\mathrm{Cu}$ to the mitochondria for the assembly of a functional cytochrome oxidase complex and cytosolic enzymes such as $\mathrm{Cu} / \mathrm{Zn}$ superoxide dismutase. In this manner COX17 would contribute to the increase in activity of specific enzymes that are required to preserve organelle functionality in a number of biotic and abiotic stress situations (Balandin and Castresana, 2002). The CCS gene, homolog of the yeast LY7 gene, has been identified in tomato (Lycopersicon esculentum; LeCCS) (Zhu et al., 2000), Arabidopsis thaliana (Wintz and Vulpe, 2002), and potato (Solanum tuberosum; StCCS) (Trindade et al., 2003). StCCS gene expression was induced by auxin which is known to play a role in different stages of potato development. Auxins have a promoting effect on cell elongation/expansion. Surprisingly, no reports have been published until now on the presence of CCS in leaves of any plant species. Moreover, potato plants sprayed with $\mathrm{CuSO}_{4}$ did not respond with a significant change in StCCS expression. Because both isoforms of $\mathrm{Cu} / \mathrm{ZnSOD}$, cytosolic and chloroplastic, are expressed in leaves, one would expect that the $\mathrm{Cu}$ chaperone for these enzymes would also be present in the same tissues. This is consistent with the inhibition of StCCS gene expression observed when potato plants were grown in vitro in media supplemented with $10 \mathrm{mM} \mathrm{CuSO}_{4}$. This unexpected finding may be explained if the presence of a chaperone were not required for the incorporation of $\mathrm{Cu}$ in the SOD when $\mathrm{Cu}$ is present at high concentrations in leaves.
Despite their role in $\mathrm{Cu}$ homeostasis, neither $\mathrm{CCH}$ nor RAN1 are induced by $\mathrm{Cu}$ treatment, indicating that they might be more important in helping cells cope with $\mathrm{Cu}$ deficit than $\mathrm{Cu}$ excess. In contrast, activation of AtCOX17 gene expression in response to $\mathrm{Cu}$ treatment might be an indication of a function like metallothioneins. Thus, further experimental support is necessary to establish the function of these proteins.

Other possible Cu-transporters: A novel family of related proteins which are implicated in the transport of divalent metal ions are the so-called N-ramp transporters. The $N$-ramp gene family has been highly conserved during evolution and homologues have been found in a wide range of living organisms. In plants, investigations of the N-ramp family have been largely restricted to rice (Oryza sativa) where three $N$-ramp gene homologues have been identified, OsNramp1, OsNaramp2 and a partial length of OsNramp3 (Belouchi et al., 1995, 1997). Subsequently, two Arabidopsis genes were identified (Alonso et al., 1999) which show similarity to Nramps. More recently, three additional genomic sequences from Arabidopsis with homology to Nramps have been found denominated AtNramp1, AtNramp3 and AtNramp4. Pairwise comparisons of similarities between each of these genes suggests that the plant Nramps can be broadly divided into two groups: 1) OsNramp1, OsNramp3 and AtNramp5 which share high similarity and 2) OsNramp2, AtNramp1, AtNramp2, AtNramp3 and AtNramp4, which have lower similarity to group (1). This finding could suggest the possibility of subgroups that may vary in their substrate specificity, although this remains to be demonstrated. As with other members of this family, the plant Nramp proteins have 12 predicted transmembrane domains, however, they also possesses a long intracellular C-terminal tail which is unique to the Nramp proteins. A transport function for the plant Nramp homologues remains to be formally demonstrated; however there is good evidence from studies with yeast for a role of the Nramp proteins in divalent cation transport. In Arabidopsis Nramp1 (AtNramp1) confers tolerance to toxic concentrations of external Fe(II) (Curie et al., 2000). Homologues of the Nramp family have also been identified in soybean and proposed to be involved in Fe(II) transport and $\mathrm{Fe}$ homeostasis in the nodule to support symbiotic $\mathrm{N}_{2}$ fixation (Kaiser et al., 2003). However, they have also been shown to mediate the uptake of other metal ions such as $\mathrm{Cu}$ in yeast. Therefore a similar function in plants should be not discarded. 
The mechanisms developed in the acquisition of essential heavy metal micronutrients have not been clearly defined although a number of genes have now been identified which encode potential transporters. There are still no indications of how they may be regulated in higher plants, but this could occur potentially at the transcriptional level (control on initiation rates, mRNA stability, differential mRNA splicing) or at the post translational level (targeting, stability). Many metal transporters in other organisms are regulated at the transcriptional level by extracellular metal concentrations via transcription factor proteins (Radisky, 1999). Recently, Jonak et al. (2004) observed that excess $\mathrm{Cu}$ activated mitogenactivated protein kinases (MAPKs) suggesting that MAPK pathways are activated in response to excess $\mathrm{Cu}$. MAPKs are involved in signal transduction induced by heavy metals and protein phosphorylation events.

\section{Tolerance mechanisms to copper toxicity}

Tolerance to heavy metals in plants may be defined as the ability to survive in soils that are toxic to other plants and is manifested by an interaction between a genotype and its environment (Macnair et al., 2000). The term is frequently used in the literature in a broader sense to include changes that may occur experimentally in the sensitive response to heavy metals. Tolerance to high concentrations of metals in species and cultivars that can grow on metal-polluted soil could be achieved by a range of potential mechanisms at the cellular level that might be involved in detoxification. These mechanisms appear to be involved primarily in avoiding the accumulation of toxic concentrations at sensitive sites within the cell preventing the damaging effects rather than developing proteins that can resist the heavy metal effects. The potential cellular mechanisms involved in tolerance include those involving $i$ ) reduction of metal-uptake through micorrhiza action or extracellular exudates; ii) stimulation of the efflux pumping of the metal at the plasma membrane; iii) chelation of metals by phytochelatins, metallothioneins, organic acids or heat shock proteins; iv) compartmentation of metals in the vacuole (Hall, 2002). There is little evidence that tolerant species or ecotypes show an enhanced oxidative defence; rather, tolerant plants show enhanced avoidance and homeostatic mechanisms to prevent the stress (De Vos et al., 1991; Dietz et al., 1999).

Van Thichelen et al. (2001) showed that some mycorrhizal species protect Pinus sylvestris against $\mathrm{Cu}$ toxicity extracellularly, although the amount of $\mathrm{Cu}$ retained by different fungi vary considerably. The mechanisms employed by the fungi are probably through binding to extracellular materials. Organic acids excreted by plants can facilitate metal uptake, but these molecules can also inhibit metal acquisition by forming a complex with it outside the root so that it is not taken up. In this sense, citrate appears to be responsible for $\mathrm{Cu}$ tolerance in Arabidopsis thaliana (Murphy et al., 1999).

On the other hand, once inside the root cells, metals are translocated by membrane metal transporters and metal-binding proteins to their final destination. This process involves specific proteins that must maintain a fine balance between there being enough essential metals available for metabolic functions and at the same time avoiding deficiency or toxicity. Excess metals are stored in a location where the metal can do the least harm to cellular processes. This involves storage in special cellular compartments such as the vacuole. Sequestration may also be in the apoplast, or in specialized cells such as epidermal cells and trichomes. Metallothioneins and phytochelatins are metal chelating molecules that may also play a role in $\mathrm{Cu}$ tolerance (Zhou and Goldsbrough, 1995; Rauser, 1995; Cobbet and Goldsbrough, 2002). Metallothioneins (MT) are cysteine-rich polypeptides encoded by a family of genes. In contrast, phytochelatins (PC) are a family of enzymatically-synthetized cysteine-rich peptides. There is evidence to support that MTs are involved in $\mathrm{Cu}$ tolerance. Expression of some MT genes is induced by $\mathrm{Cu}: i$ ) the level of expression of the 2-type MT gene correlates closely with $\mathrm{Cu}$ tolerance in a group of Arabidopsis thaliana ecotypes (Murphy and Taiz, 1995); ii) the expression of 2-type MT is elevated in a $\mathrm{Cu}$-sensitive mutant that accumulates $\mathrm{Cu}$ (van Vliet et al., 1995); iii) Cu tolerance in the metallophyte plant Silene vulgaris is associated with increased levels of a 2b-type MT (van Hoof et al., 2001); iv) the yeast MT CUP1 gene introduced into tobacco plants contributes to $\mathrm{Cu}$ metal phytoextraction (Thomas et al., 2003). However, a clear role of PCs in $\mathrm{Cu}$ detoxification has not been shown. $\mathrm{Cu}$ is a strong activator of $\mathrm{PC}$ biosynthesis but PC-deficient mutants show relatively little sensitivity to $\mathrm{Cu}$. Since PCs can form complexes with $\mathrm{Cu}$ it may be possible that $\mathrm{PC}-\mathrm{Cu}$ complexes are not sequestered in the vacuole (Cobbet and Goldsbrough, 2002).

P-type $\mathrm{Cu}$ transporting ATPases are thought to be important not only in obtaining sufficient amounts of heavy metal ions for essential cell functions but also in preventing accumulations of these ions to toxic levels. On the other hand, $\mathrm{Cu}$ ions are chelated by specific chaperones and delivered to $\mathrm{Cu}$ pumps for transport into organelles or directly to cytosolic $\mathrm{Cu}$-dependent proteins. Thus, both $\mathrm{Cu}$ chelation 
and $\mathrm{Cu}$ pumping activity are likely to be required not only for $\mathrm{Cu}$-uptake but also for other processes. Thus, these transporters and chaperones could be involved in the overall strategy of heavy metal tolerance. A possible role of metal transporters and chaperones in phytoremediation (defined as the use of green plants to remove pollutants from the environment or to render them harmless) has been proposed. However, our knowledge of the transport processes for heavy metals across plant membranes at the molecular level is still rudimentary in most cases. A comprehensive understanding of metal transport in plants will be essential for developing strategies to genetically engineer plants that accumulate specific metals, either for use in phytoremediation or to improve human nutrition (Salt et al., 1998; Pilon-Smits and Pilon, 2002).

\section{REFERENCES}

Alonso JM, Hirayama T, Roamn G, Nourizadeh S, Ecker JR (1999) EIN2, a bifunctional transducer of ethylene and stress response in Arabidopsis. Science 284:2148-2152.

Arellano JB, Lázaro JJ, López-Gorgé J, Barón M (1995) The donor side of PSII as the copper-inhibitory binding site. Photosynth. Res. 45:127-134.

Aro EM, McCaffery S, Anderson JM (1993) Photoinhibition and $\mathrm{D} 1$ protein degradation in peas acclimated to different growth irradiances. Plant Physiol. 103:835-843.

Axelsen KB, Palmgren MG (2001) Inventory of the superfamily of P-type ion pumps in Arabidopsis. Plant Physiol. 126:696-706.

Baker DE, Senef JP (1995) Copper. In: Alloway BJ (ed), Heavy metals in soils, pp.179-205. Blackie Academic and Professional, London.

Balandin T, Castresana C (2002) AtCOX17, an Arabidopsis homolog of the yeast copper chaperone COX17. Plant Physiol. 129:1852-1857.

Barón M, López-Gorgé J, Lachica M, Sadmann G (1992) Changes in carotenoids and fatty acids in photosysyem II of Cu-deficient pea plants. Physiol. Plant. 84:1-5.

Barón M, Arellano JB, López-Gorgé J (1995) Copper and photosystem II: A controversial relationship. Physiol. Plant. 94:174-180.

Baszynski T, Ruszkowska M, Król M, Tukendorf A, Wolinska D (1978) The effect of copper deficiency on the photosynthetic apparatus of higher plants. Z. Pflanzenphysiol. 89:207-216.

Baszynski T, Tukendorf A, Ruszkowska M, Skórzynska E, Maksymiec W (1988) Characteristics of the photosynthetic apparatus of copper non-tolerant spinach exposed to excess copper. J. Plant Physiol. 132:708-713.

Baszynski T, Krupa Z (1995) Some aspects of heavy metal toxicity towards photosynthetic apparatus-direct an indirect effects on light and dark reactions. Acta Physiol. Plant. 17:177-191.
Baxter I, Tchieu J, Sussman MR, Boutry M, Palmgren MG, Gribskov M, Harper JF, Axelsen KB (2003) Genomic comparison of P-type ATPase ion pumps in Arabidopsis and rice. Plant Physiol. 132:618-628.

Belouchi A, Cellier M, Kwan T, Saini HS, Leroux G, Gros $P$ (1995) The macrophage-specific membrane protein Nramp controlling natural resistance to infections in mice has homologues expressed in the root system of plants. Plant Mol. Biol. 29:1181-1196.

Belouchi A, Kwan T, Gros P (1997) Cloning and characterization of the OsNramp family from Oryza sativa, a new family of membrane proteins possibly implicated in the transport of metal ions. Plant Mol. Biol. 33:1085-1092.

Bernal M, Roncel M, Ortega JM, Picorel R, Yruela I (2004) Copper effect on cytochrome $b_{559}$ of photosystem II under photoinhibitory conditions. Physiol. Plant. 120:686-694.

Bohner H, Böhme H, Böger P (1980) Reciprocal formation of plastocyanin and cytochrome c-553 and the influence of cupric ion on photosynthetic electron transport. Biochim. Biophys. Acta 592:103-112.

Burda K, Kruk J, Schmid GH, Strzalka K (2003) Inhibition of oxygen evolution in photosystem II by $\mathrm{Cu}$ (II) ions is associated with oxidation of cytochrome $b_{559}$. Biochem. J. 371:597-601.

Cedeño-Maldonado A, Swader JA (1972) The cupric ion as an inhibitor of photosynthetic electron transport in isolated chloroplasts. Plant Physiol. 50:698-701.

Ciscato M, Valcke R, van Loven K, Clijsters H, Navari-Izzo F (1997) Effects of in vivo copper treatment on the photosynthetic apparatus of two Triticum durum cultivars with different stress sensitivity. Physiol. Plant. 100:901-908.

Cobbet C, Goldsbrough P (2002) Phytochelatins and metallothioneins: roles in heavy metal detoxification and homeostasis. Annu. Rev. Plant Biol. 53:159-182.

Cobbet CS, Hussain D, Haydon MJ (2003) Structural and functional relationships between type $1_{B}$ heavy metal transporting P-type ATPases in Arabidopsis. New Phytol. 159:315-321.

Company P, González-Bosch C (2003) Identification of a copper chaperone from tomato fruits infected with Botrytis cinerea by differential display. Biochim. Biophys. Res. Comm. 304:825-830.

Curie C, Alonso JM, Le Jean M, Ecker JR, Briat JF (2000) Involvement of Nramp 1 from Arabidopsis thaliana in iron transport. Biochem. J. 347:749-755.

Dietz K-J, Baier M, Krämer U (1999) Free radicals and reactive oxygen species as mediators of heavy metal toxicity in plants. In: Prasad MNV, Hagemeyer J (eds), Heavy metal stress in plants: from molecules to ecosystems, pp.73-97. Springer-Verlag, Berlin.

De Vos CHR, Schat H, De Waal MAM, Voojis R, Ernst WHO (1991) Increased resistance to copper-induced damage of the root cell plasmalemma in copper tolerant Silene cucubalus. Physiol. Plant. 82:523-528.

De Vos CHR, Vonk MJ, Voojis R, Schat H (1992) Glutathione depletion due to copper-induced phytochelatin synthesis causes oxidative stress in Silene cucubalus. Plant Physiol. 98:853-858. 
Drazkiewicz M, Skórzynska-Polit E, Krupa Z (2003) Response of the ascorbate-glutathione cycle to excess copper in Arabidopsis thaliana (L.). Plant Sci. 164:195-202.

Droppa M, Masojidek J, Rózsa Z, Wolak A, Horváth LI, Farkas T, Horváth G (1987) Characteristics of Cu deficiencyinduced inhibition of photosynthetic electron transport in spinach chloroplasts. Biochim. Biophys. Acta 891:75-84

Droppa M, Horváth G (1990) The role of copper in photosynthesis. Plant Sci. 9:111-123.

Eide DJ (1998) The molecular biology of metal ion transport in Saccharomyces cerevisiae. Annu. Rev. Nutr. 118:441-69.

Fox TC, Guerinot ML (1998) Molecular biology of cation transport in plants. Annu. Rev. Plant Physiol. 49:669-696.

Gunning B, Schartz O (1999) Confocal microscopy of thylakoid autofluorescence in relation to origin of grana and phylogeny in the green algae. Aust. J. Plant Physiol. 26: 695-708.

Gupta M, Cuypers A, Vangronsveld J, Clijsters H (1999) Copper affects the enzymes of the ascorbate-glutathione cycle and its related metabolites in the roots of Phaseolus vulgaris. Physiol. Plant. 106:262-267.

Hall JL (2002) Cellular mechanisms for heavy metal detoxification and tolerance. J. Exp. Bot. 53:1-11.

Halliwell B, Gutteridge JMC (1984) Oxygen toxicity, oxygen radicals, transition metals and disease. Biochem. J. 219:1-14.

Harris ED (2000) Cellular copper transport and metabolism. Annu. Rev. Nutr. 20:291-310.

Henriques FS (1989) Effects of copper deficiency on the photosynthetic apparatus of sugar beet (Beta vulgaris L.) J. Plant Physiol. 135:453-458.

Himelblau E, Mira H, Lin SJ, Culotta VC, Peñarrubia L, Amasino RM (1998) Identification of a functional homolog of the yeast copper homeostasis gene ATX1 from Arabidopsis. Plant Physiol. 117:1227-1234.

Himelblau E, Amasino RM (2000) Delivering copper within plant cells. Curr. Opin. Plant Biol. 3:205-210.

Hirayama T, Kieber JJ, Hirayama N, Kogan M, Guzman P, Nourizadeh S, Alonso JM, Dailey WP, Dancis A, Ecker JR (1999) Responsive-to-antagonist1, a Menkes/Wilson disease-related copper transporter, is required for ethylene signaling in Arabidopsis. Cell 97:383-393.

Hirayama T, Alonso JM (2000) Ethylene captures a metal! Metal ions are involved in ethylene perception and signal transduction. Plant Cell Physiol. 41:548-555.

Hsu BD, Lee JY (1988) Toxic effects of copper on photosystem II of spinach chloroplasts. Plant Physiol. 87:116-119.

Jasiewicz C (1981) The effect of copper and application of different forms of nitrogen on some physiological indices of maize. Acta Agraria et Silvestria Agraria 20:95-106.

Jegerschöld C, Arellano JB, Schöder WP, van Kan PJM, Barón M, Styring S (1995) Copper (II) inhibition of electron transfer through photosystem II studied by EPR spectroscopy. Biochemistry 34:12747-12754.

Jegerschöld C, MacMillan F, Lubitz W, Rutherford AW (1999) Effects of copper and zinc ions on photosystem II studied by EPR spectroscopy. Biochemistry 38:12439-12445.
Kaiser BN, Moreau S, Castelli J, Thomson R, Lambert A, Bogliolo S, Puppo A, Day DA(2003) The soybean NRAMP homologue, GmDMT1 is a symbiotic divalent metal transporter capable of ferrous iron transport. Plant J. 35:295-304.

Kampfenkel K, Kushinr S, Babychuk E, Inzé D, van Montagu M (1995) Molecular characterization of a putative Arabidopsis thaliana copper transporter and its yeast homologue. J. Biol. Chem. 270:28479-28486.

Králová K, Sersen F, Blahová M (1994) Effects of Cu(II) complexes on photosynthesis in spinach chloroplasts. Aqua (aryloxiacetato)copper (II) complexes. Gen. Physiol. Biophys. 13:483-491.

Labbé S, Thiele DJ (1999) Pipes and wiring: the regulation of copper uptake and distribution in yeast. Trends Microbiol. 7:500-505.

Lidon FC, Henriques FS (1991) Limiting step in photosynthesis of rice plants treated with varying copper levels. J. Plant Physiol. 138:115-118.

Lidon FC, Henriques FS (1993) Changes in the thylakoid membrane polypeptide patterns triggered by excess $\mathrm{Cu}$ in rice. Photosynthetica 28:109-117.

Luna CM, González CA, Trippi VS (1994) Oxidative damage caused by excess of copper in oat leaves. Plant Cell Physiol. 35:11-15.

Macnair MR, Tilstone GH, Smith SE (2000) The genetics of metal tolerance and accumulation in higher plants. In: Terry N, Banuelos G (eds), Phytoremediation of contaminated soil and water, pp.235-250. CRC Press LLC.

Markossian KA, Kurganov BI (2003) Copper chaperones, intracellular copper trafficking proteins. Function, structure, and mechanism of action. Biochemistry (Mosc) 68:827-837

Marschner H (1995) Mineral nutrition of higher plants. Academic Press, London.

Maksymiec W, Russa R, Urbanik-Sypniewska T, Baszynski $\mathrm{T}$ (1994) Effect of excess $\mathrm{Cu}$ on the photosynthetic apparatus of runner bean leaves treated at two different growth stages. Physiol. Plant. 91:715-721.

Maksymiec W, Baszynski T (1999) The role of $\mathrm{Ca}^{2+}$ ions in modulating changes induced in bean plants by an excess of $\mathrm{Cu}^{2+}$ ions. Chlorophyll fluorescence measurements. Physiol. Plant. 105:562-568.

Meharg AA(1994) Integrated tolerance mechanisms-constitutive and adaptive plant-responses to elevated metal concentrations in the environment. Plant Cell Environ. 17:989-993.

Mira H, Martínez-García F, Peñarrubia L (2001a) Evidence for the plant-specific intercellular transport of the Arabidopsis copper chaperone CCH. Plant J. 25:521-528.

Mira H, Vilar M, Pérez-Raya E, Peñarrubia L (2001b) Functional and conformational properties of the exclusive $\mathrm{C}$ domain from the Arabidopsis copper chaperone (CCH) Biochem. J. 15:545-549.

Mohanty N, Vass I, Demeter S (1989) Copper toxicity affects photosystem II electron transport at the secondary quinone acceptor $\mathrm{Q}_{\mathrm{B}}$. Plant Physiol. 90:175-179.

Murphy A, Taiz L (1995) A new vertical mesh transfer technique for metal-tolerance studies in Arabidopsis. Plant Physiol. 108:29-38. 
Murphy AS, Eisenger WR, Shaff JE, Kochian LV, Taiz L (1999) Early copper-induced leakage of $\mathrm{K}^{+}$from Arabidopsis seedlings is mediated by ion channels and coupled to citrate efflux. Plant Physiol. 121:1375-1382.

Navari-Izzo F, Quartacci MF, Pinzino C, Dalla Vecchia F, Sgherri CLM (1998) Thylakoid-bound and stromal enzymes in wheat treated with excess copper. Physiol. Plant. 104:630-638.

Nelson N (1999) Metal ion transporters and homeostasis. EMBO J. 18:4361-4371.

Ouzounidou G, Eleftheriou EP, Karataglis S (1992) Ecophysiological and ultrastructural effects of copper in Thlaspi ochroleucum (Cruciferae). Can. J. Bot. 70:947-957.

Ouzounidou G, Moustakas M, Strasser RJ (1997) Sites of action of copper in the photosynthetic apparatus of maize leaves: kinetic analysis of chlorophyll fluorescence, oxygen evolution, absorption changes and thermal dissipation as monitored by photoacoustic signals. Aust. J. Plant Physiol. 24:81-90.

Peña MMO, Lee J, Thiele DJ (1999) A delicate balance: homeostatic control of copper uptake and distribution. J. Nutr. 129:1251-1260.

Pilon-Smits E, Pilon M (2002) Phytoremediation of metals using transgenic plants. Crit. Rev. Plant Sci. 21:439-456.

Quartacci MF, Pinzino C, Sgherri CLM, Dalla Vecchia F, Navari-Izzo F (2000) Growth in excess copper induces changes in the lipid composition and fluidity of PSII-enriched membranes in wheat. Physiol. Plant. 108:87-93.

Palmgren MG, Axelsen KB (1998) Evolution of P-type ATPases. Biochim. Biophys. Acta 1365:37-45.

Pätsikkä E, Aro E-M, Tyystjärvi E (1998) Increase in the quantum yield of photoinhibition contributes to copper toxicity in vivo. Plant Physiol. 117:619-627.

Pätsikkä E, Aro E-M, Tyystjärvi E (2001) Mechanism of copper-enhanced photoinhibition in thylakoid membranes. Physiol. Plant. 113:142-150.

Pätsikkä E, Kairavuo M, Sersen F, Aro E-M, Tyystjärvi E (2002) Excess copper predisposes photosystem II to photoinhibition in vivo by outcompeting iron and causing decrease in leaf chlorophyll. Plant Physiol. 129:1359-1367.

Prasad MNV, Strzalka K (1999) Impact of heavy metals on photosynthesis. In: Prasad MNV, Hagemeyer J (eds), Heavy Metal Stress in Plants, pp. 117-138. Springer Publishers, Berlin.

Puig S, Thiele DJ (2002) Molecular mechanisms of copper uptake and distribution. Curr. Opin. Chem. Biol. 6:171-180.

Radisky D, Kaplan J (1999) Regulation of transition metal transport across the yeast plasma membrane. J. Biol. Chem. 274:4481-4484.

Raven JA, Evans MCW, Korb RE (1999) The role of trace metals in photosynthetic electron transport in $\mathrm{O}_{2}$-evolving organisms. Photosynth. Res. 60:111-149.

Rauser WE (1995) Phytochelatins and related peptides. Plant Physiol. 109:1141-1149.

Renger G, Gleiter HM, Haag E, Reifarth F (1993) Photosystem II: Thermodynamics and kinetics of electron transport from $\mathrm{Q}_{\mathrm{A}}{ }^{-}$to $\mathrm{Q}_{\mathrm{B}}\left(\mathrm{Q}_{\mathrm{B}}{ }^{-}\right)$and deleterious effects of copper (II). Z. Naturforsch. 48c:234-240.
Rodríguez FI, Esch JJ, Hall AE, Binder BM, Schaller GE, Bleecker AB (1999) A copper cofactor for the ethylene receptor ETR1 from Arabidopsis. Science 283:996-998.

Roncel M, Ortega JM, Losada M (2001) Factors determining the special redox properties of photosynthetic cytochrome b559. Eur. J. Biochem. 268:4961-4968.

Sabat SC (1996) Copper ion inhibition of electron transport activity in sodium chloride washed photosystem II particle is partially prevented by calcium ion. Z. Naturforsch. 51c:179-184.

Sadmann G, Böger P (1980) Copper-mediated lipid peroxidation processes in photosynthetic membranes. Plant Physiol. 66:797-800.

Salt DE, Smith RD, Raskin I (1998) Phytoremediation. Annu. Rev. Plant Physiol. Plant Mol. Biol. 49:643-668.

Salt DE, Krämer U (2000) Mechanisms of metal hyperaccumulation in plants. In: Raskin I, Ensley BD (eds), Phytoremediation of toxic metals using plants to clean up the environment, pp.231-246. John Wiley and Sons, Chichester, UK.

Samson G, Morissette JC, Popovic R (1988) Copper quenching of the variable fluorescence in Dunaliella tertiolecta. New evidence for a copper inhibition effect on PSII photochemistry. Photochem. Photobiol. 84:329-332.

Samuelsson G, Öquist G (1980) Effects of copper chloride on photosynthetic electron transport and chlorophyll-protein complexes of Spinacea oleracea. Plant Cell Physiol. 21:445-454.

Sancenón V, Puig S, Mira H, Thiele DJ, Peñarrubia L (2003) Identification of a copper transporter family in Arabidopsis thaliana. Plant Mol. Biol. 51:577-587.

Sancenón V, Puig S, Mateu-Andrés I, Dorcey E, Thiele DJ, Peñarrubia L (2004) The Arabidopsis copper transporter COPT1 functions in root elongation and pollen development. J. Biol. Chem. 279:15348-15355.

Schröder WP, Arellano JB, Bittner T, Barón M (1994) Flashinduced absorption spectroscopy studies of copper interaction with photosystem II in higher plants. J. Biol. Chem. 52:32865-32870.

Sersen K, Králová K, Bumbálová A, Svajlenova O (1997) The effect of $\mathrm{Cu}$ (II) ions bound with tridentate Schiff base ligands upon the photosynthetic apparatus. J. Plant Physiol. 151:299-305.

Shikanai T, Müller-Moulé P, Munekage Y, Niyogi KK, Pilon M (2003) PPA1, a P-type ATPase of Arabidopsis, functions in copper transport in chloroplasts. Plant Cell 15: 1333-1346.

Shioi Y, Tamai H, Sasa T (1978a) Effects of copper on photosynthetic electron transport systems in spinach chloroplasts. Plant Cell Physiol. 19:203-209.

Shioi Y, Tamai H, Sasa T (1978b) Inhibition of photosystem II in the green algae Ankistrodesmus falcatus by copper. Plant Physiol. 44:434-438.

Solioz M, Vulpe (1996) CPx-type ATPases: a class of P-type ATPases that pump heavy metals. Trends Biochem. Sci. 21:237-241.

Southron JL, Basu U, Taylor GJ (2004) Complementation of Saccharomyces cerevisiae ccc 2 mutant by a putative P1BATPase from Brassica napus supports a copper-transporting function. FEBS Lett. 566:218-222. 
Stauber JL, Florence TM (1987) Mechanism of toxicity of ionic copper and copper complexes to algae. Mar. Biol. 94:511-519.

Stohs SJ, Bagchi D (1995) Oxidative mechanisms in the toxicity of metal ions. Free Radic. Biol. Med. 18:321-336.

Tabata K, Kashiwagi S, Mori H, Ueguchi C, Mizuno T (1997) Cloning of a cDNA encoding a putative metal-transporting P-type ATPase from Arabidopsis thaliana. Biochem. Biophys. Acta 1326:1-6.

Thomas JC, Davies EC, Malick FK, Endreszi C, Williams CR, Abbas M, Petrella S, Swisher K, Perron M, Edwards R, Osenkowski P, Urbanczyk N, Wiesend WN, Murray KS (2003) Yeast metallothionein in transgenic tobacco promotes copper uptake from contaminated soils. Biotechnol. Prog. 19:273-280.

Trindade LM, Horváth BM, Bergervoet MJE, Visser RGF (2003) Isolation of a gene encoding a copper chaperone for copper/zinc superoxide dismutase and characterization of its promoter in potato. Plant Physiol. 133:618-629.

Van Assche F, Clijsters H (1990) Effects of metals on enzyme activity in plants. Plant Cell Environ. 13:195-206.

Van Hoof NA, Hassinen VH, Hakvoort HW, Ballintijn KF, Schat H, Verkleij JA, Ernst WH, Karenlampi SO, Tervahauta AI (2001) Enhanced copper tolerance in Silene vulgaris (Moench) Garcke populations from copper mines is associated with increased transcript levels of a $2 \mathrm{~b}$-type metallothionein gene. Plant Physiol. 126:1519-1526.

Van Tichelen KK, Colpaert JV, Vangronsveld J (2001) Ectomycorrhizal protection of Pinus sylvestris against copper toxicity. New Phytol. 150:203-213.

Van Vliet C, Anderson CR, Cobbet CS (1995) Copper-sensitive mutant of Arabidopsis thaliana. Plant Physiol. 109: 871-878.

Vierke G, Struckmeier P (1977) Binding of copper (II) to protein of the photosynthetic membrane and its correlation with inhibition of electron transport in class II chloroplasts of spinach. Z. Naturforsch. 32c:605-610.

Voskoboinik I, Camakaris J, Mercer JFB (2002) Understanding the mechanism and function of copper P-type ATPases. Adv. Protein Chem. 60:123-150.
Wang H, Shan X-q, Wen B, Zhang S, Wang Z-j (2004) Responses of antioxidative enzymes to accumulation of copper in a copper hyperaccumulator of Commoelina communis. Arch. Environ. Contam. Toxicol. 47:185-192.

Williams LE, Pittman JK, Hall JL (2000) Emerging mechanisms for heavy metal transport in plants. Biochim. Biophys. Acta 1465:104-126.

Wintz H, Vulpe C (2002) Plant copper chaperones. Biochem. Soc. Trans. 30:732-735

Yruela I, Montoya G, Alonso PA, Picorel R (1991) Identification of the pheophytin- $\mathrm{Q}_{\mathrm{A}}$-Fe domain of the reducing side of the photosystem II as the $\mathrm{Cu}(\mathrm{II})$-inhibitory binding site. J. Biol. Chem. 266:22847-22850.

Yruela I, Montoya G, Picorel R (1992) The inhibitory mechanism of $\mathrm{Cu}$ on the photosystem II electron transport from higher plants. Photosynth. Res. 33:227-233.

Yruela I, Alfonso M, Ortiz de Zarate I, Montoya G, Picorel R (1993) Precise location of the $\mathrm{Cu}$-inhibitory binding site in higher plant and bacterial photosynthetic reaction centers as probed by light-induced absorption changes. J. Biol. Chem. 268:1684-1689.

Yruela I, Gatzen G, Picorel R, Holzwarth AR (1996a) Cu(II)inhibitory effect on photosystem II from higher plants. A picosecond time-resolved fluorescence study. Biochemistry 35:9469-9474.

Yruela I, Pueyo JJ, Alonso PJ, Picorel R (1996b) Photoinhibition of photosystem II from higher plants: effect of copper inhibition. J. Biol. Chem. 271:27408-27415.

Yruela I, Alfonso M, Barón M, Picorel R (2000) Copper effect on the protein composition of photosystem II. Physiol. Plant. 110:551-557.

Zhou J, Goldsbrough PB (1995) Structure, organization and expression of the metallothionein gene family in Arabidopsis. Mol. Gen. Genet. 248:318-328.

Zhu H, Shipp E, Sanchez RJ, Liba A, Stine JE, Hart PJ, Gralla EB, Nersissian AM, Valentine JS (2000) Cobalt (2+) binding to human and tomato copper chaperone for superoxide dismutase: implications for the metal ion transfer mechanism. Biochemistry 39:5413-5421. 